REFLECTIONS:

NEUROLOGY AND

THE HUMANITIES

Section Editor

Anne W. McCammon,

MD, FAAN

\title{
The baby with the bucket list
}

Asad I. Mian, MD, PhD

Correspondence to

Dr. Mian:

amian@bcm.edu
"Betty is dead, Baba. My friend told me," said Noori, my 5-year-old kindergartner, when I picked her up from school that day. I had known that since it was on $\mathrm{CNN}$.

Betty wasn't quite 6 months old and had recently been diagnosed with spinal muscular atrophy (SMA). Although I am a pediatrician, I must remind myself that everything becomes recent when you are just 6 months old. Baby Betty, as she was fondly called, became a household name after the blog written by her dad went viral. Betty was the only baby I had known with a bucket list. Several things were mentioned on the list: being able to sit up, kissing and hugging mommy and daddy, getting a tattoo, manicure and pedicure, and such. Given her diagnosis, the remarkable infant managed to achieve quite a few of the items listed there, and in the process she managed to win thousands of hearts the world over.

Betty was very special for a number of reasons. I got to know the baby entirely through Noori and the baby's mother, Gloria, who was a kindergarten teacher...no...THE kindergarten teacher who taught Noori. She was the kind of kindergarten teacher that I never had when I was Noori's age. Gloria and her kindergarten classroom were the inspiration for Noori and me to start writing a joint memoir called The Kindergarten Diaries, through which Mr. Teddy Graham, Valentine's Day, anniversaries, and the like, were captured through the eyes, mind, and heart of the daughter-dad duo.

Noori learned about life through Betty. While Gloria, during her pregnancy, was teaching at school, Noori would give me constant updates. "We need to be very careful when we are around Ms. Gloria because she has a little baby inside of her." When Gloria went on maternity leave, "Ms. Gloria and John are very excited that they will have their baby girl soon." Her excitement knew no bounds when she rushed home one day with the good news about Betty's birth. That excitement peaked when Noori got to see and touch Betty the day Gloria took her to school for show and tell. Soon after returning to her class Gloria had to take an unanticipated leave. Noori was the first one to tell me that baby Betty was unwell. The e-mail sent out to us, as class parents, was a bad omen, particularly for me. During my first year of pediatrics residency, I had been part of a team taking care of a baby diagnosed with SMA. That baby I will remember for the rest of my life. She was a bundle of joy to behold, entirely because of her animated expression through her eyes. By then, she had lost motor function in her arms and legs. Yet, in that paralyzed state, her eyes did the talking for her; eyes that communicated happiness and contentment when she had been nursed and burped by her doting mother. That baby succumbed to her illness at 6 months of age.

All that rushed through my mind (and heart) and I felt compelled to approach Gloria. Partly this was because of my expertise in pediatrics and genetics, knowing about and dealing with patients with SMA, but more so because my child's favorite teacher was surely suffering. When I spoke to Gloria, I did so with trepidation; neither was I Betty's physician nor had I examined the child to say much about her clinical condition. However, Gloria was extremely brave under the circumstances. And she had hope. What reason did I have to tell her about my fears, concerns, and the hopelessness inherent in SMA? I could have made it sound academic, with emphasis on the molecular genetics process, or I could have given her worst-case scenarios. Based on medical literature and personal experience, the severe kinds were always bad. I didn't know how I was going to go through that conversation, and I don't know how I did during that session.

Noori learned about death through Betty. A few months ago, while I was visiting Karachi, I heard about the test confirming Betty's diagnosis of SMA, and my worst fears were realized. At that time I wished that I was in Houston to meet with Gloria, John, and Betty.

I despaired, as did Noori. I think she dealt with it better. She mentioned how baby Betty was "very very sick." Her friends at school were her source of information that she was relaying to me. I did the token talk about how the body can be affected by illness and that, at times, nothing can be done and when the person stops breathing there is death.

On our walk home from school the day Betty died, I asked Noori what death was and what Betty's passing meant to her. She shrugged her shoulders, looked slightly wistful, and with a hint of irritation she said, "I don't know!" She then bent to pick up some wild flowers by the roadside. For Betty, was the thought that crossed my mind. How was I to explain illness, let alone fatal illness, dying, and death, to my 5-year-old? My 


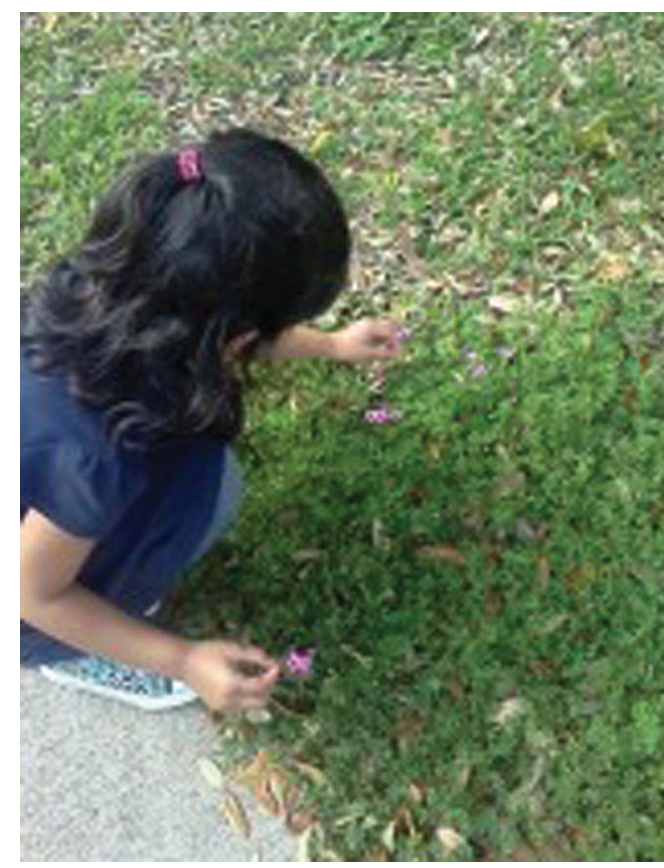

Noori picking wildflowers for baby Betty medical training did not prepare me for that. Life itself prepared me for that. I realized that a little more time and distance from the recent event might help Noori gain a deeper perspective of dying and death.

While walking, I pondered what death was. Was it simply the absence of life? What about being clinically alive but being dead to life around you — a spiritual death? I recall asking Rayaan, my 10-year-old son, who was also with us then, what Betty's death meant to him. In his classic manner, he mumbled something that I could not quite comprehend-entirely my loss!

Once we got home, I decided against probing Noori further. Given the circumstances, I did the best I could. I played with her. I admired her signature artwork of the day. I managed to scream less at her.

Above all, I reminded myself to appreciate Noori for who she was, and to be grateful for the time I had been given to be with her.

Dedication. The author dedicates this essay to fellow travelers Betty, Gloria, and John. 


\section{Neurology}

The baby with the bucket list

Asad I. Mian

Neurology 2013;80;e30-e31

DOI 10.1212/WNL.0b013e31827f0904

\section{This information is current as of January 21, 2013}

\section{Updated Information \&} Services

\section{Subspecialty Collections}

Permissions \& Licensing

Reprints including high resolution figures, can be found at: http://n.neurology.org/content/80/4/e30.full

This article, along with others on similar topics, appears in the following collection(s):

\section{All Neuromuscular Disease}

http://n.neurology.org/cgi/collection/all_neuromuscular_disease

\section{All Pediatric}

http://n.neurology.org/cgi/collection/all_pediatric

Anterior nerve cell disease

http://n.neurology.org/cgi/collection/anterior_nerve_cell_disease Motor Control

http://n.neurology.org/cgi/collection/motor_control

Information about reproducing this article in parts (figures,tables) or in its entirety can be found online at:

http://www.neurology.org/about/about_the_journal\#permissions

Information about ordering reprints can be found online:

http://n.neurology.org/subscribers/advertise

Neurology ${ }^{\circledR}$ is the official journal of the American Academy of Neurology. Published continuously since 1951, it is now a weekly with 48 issues per year. Copyright (C 2013 American Academy of Neurology. All rights reserved. Print ISSN: 0028-3878. Online ISSN: 1526-632X.

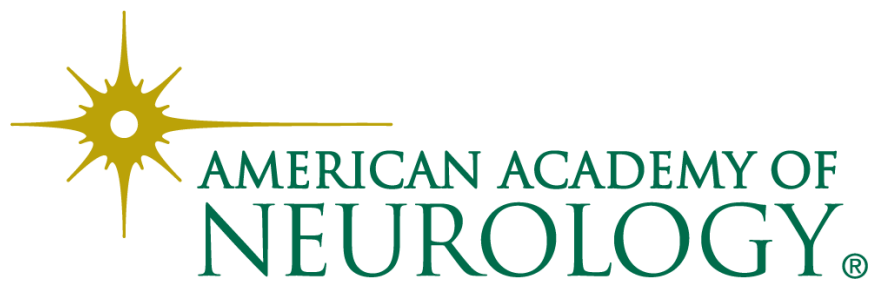

